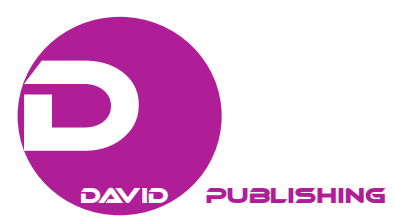

\title{
How Did the Globally Top Competitive Countries Perform?
}

\author{
Pulapa Subba Rao \\ The University of Papua New Guinea, National Capital District, Papua New Guinea
}

\begin{abstract}
Countries do also compete among themselves to develop their economies like business organizations compete. This paper assesses the performance of the top globally competitive countries in terms of the degree of globalization, international trade, investment in research and technology, tariffs, foreign direct investment, and ethical practices in carrying-out international business. Analysis of these factors indicates that all the top globally competitive countries could not exhibit corresponding performance in the globalization levels, exports, investment in research and development, attracting and providing foreign direct investment, and doing business ethically. Therefore, it is suggested that these countries should implement the practices that would reflect their position as one of the top globally competitive countries.

Keywords: Globally Competitive Countries, Index of Globalization, Corruption Index of Transparency International, Basel Index
\end{abstract}

\section{Introduction}

Countries do also compete among themselves to develop their economies as business organizations do. World Economic Forum has been constructing Global Competitiveness Index of world economies. Global Competitiveness Index measures the microeconomic and macroeconomic foundations of national competitiveness (World Economic Forum: 2014-15). World Economic Forum measures the Global Competitiveness index using 12 pillars like institutions, infrastructure, macroeconomic environment, health and primary education, higher education and training, goods market efficiency, labour market efficiency, financial market development, technological readiness, market size, business sophistication, and innovation. The Global Competitiveness assesses the competitiveness landscape and provides competitive index for 144 economies (World Economic Forum: 2014-15).

Table 1 depicts the global competitiveness index for the top 10 countries during 2012-13 to 2014-15. The top 10 globally competitive countries during the study period include Switzerland, Singapore, the USA, Finland, Germany, Japan, Hong Kong, Netherland, UK, and Sweden. Though the index of the countries varied, all these countries remain as the best globally competitive countries during 2012-13, 2013-14, and 2014-15.

Pulapa Subba Rao, pro vice-chancellor (ASA), The University of Papua New Guinea, National Capital District, Papua New Guinea.

Correspondence concerning this article should be addressed to Pulapa Subba Rao, The University of Papua New Guinea, P.O. Box: 320, University P.O. 134, National Capital District, Papua New Guinea. 
Table 1

Global Competitiveness Index During 2012-13 to 2014-15 (for Selected Countries Only)

\begin{tabular}{llll}
\hline Country & Rank for 2014-15 & Rank for 2013-14 & Rank for 2012-13 \\
\hline Switzerland & 1 & 1 & 1 \\
Singapore & 2 & 2 & 2 \\
USA & 3 & 3 & 7 \\
Finland & 4 & 8 & 10 \\
Germany & 5 & 4 & 6 \\
Japan & 6 & 6 & 3 \\
Hong Kong & 7 & 7 & 9 \\
Netherlands & 8 & 5 & 5 \\
UK & 9 & 10 & 8 \\
Sweden & 10 & 9 & 4 \\
\hline
\end{tabular}

Source: http://www.weforum.org/reports/global-competitiveness-report-2014-15, 2013-2014 and 2012-13.

\section{Literature Review}

Globally competitive countries are expected to exhibit exemplary performance in various aspects like the performance in terms of the degree of globalization, international trade, investment in research and technology, tariffs, foreign direct investment, and ethical practices in carrying-out international business. Against this background a research study is undertaken to assess the performance of the globally competitive countries against the aspects indicated earlier. Review of the existing literature on the theme of the study indicates that there are no studies dealing with the theme. However, a few studies make a mention of the performance of the countries, Deresky (2004), Mead (2005), Hodgetts, Luthans, and Doh (2008), and Subba (2014). Therefore, the present study is expected to contribute towards plugging this knowledge gap.

\section{Research Methods}

Data used for this study were collected from secondary sources like KOF Index of Globalization, World Trade Organization, UNCTAD (United Nations Conference on Trade and Development) World Investment Report, and Corruption Index of Transparency International. The study is limited to top-10 globally competitive countries based on the World Economic Forum's Global Competitiveness index for the years 2012-13, 2013-14, and 2014-15. Performance of the globally top-10 competitive countries is measured against globalization index, global trade, investment in research and development, corruption, money laundering and terrorist financing, and software piracy. Data of the performance indicators are related to different periods. As such the findings of this study are subject to these limitations.

\section{Research Results}

Globally competitive countries are expected to achieve higher degree of globalization in terms of economies, societies, and political systems. The KOF Index of Globalization, measures globalization on economic, social, political, and overall dimensions by looking at economic flows, restrictions, information flows, personal contact, and cultural proximity (http://globaledge.msu.edu/global-resources/resource/433).

Table 2 depicts KOF Index of economic, social and political globalization, and overall globalization. The top globally competitive country i.e., Switzerland scored only the 9th position in overall globalization, the 35th 
position in economic globalization, the 3rd position in social globalization, and the 11th position in political globalization. Similarly, all other top-10 global competitive countries could not retain their positions in overall globalization, economic globalization, social globalization, and political globalization. In fact, Japan's economic globalization position is as high as the 126. It is clear from this analysis that the top-10 globally competitive countries could not succeed in globalizing their economies, societies, and political systems to the extent corresponding to their positions as globally competitive countries.

Table 2

KOF Index of Economic, Social and Political Globalization for Selected Years and Countries

\begin{tabular}{lllll}
\hline Country & Overall globalization & Economic globalization & Social globalization & Political globalization \\
\hline Switzerland & 9 & 35 & 3 & 11 \\
Singapore & 5 & 1 & 2 & 85 \\
USA & 34 & 90 & 28 & 16 \\
Finland & 10 & 10 & 17 & 21 \\
Germany & 27 & 63 & 15 & 17 \\
Japan & 54 & 126 & 54 & 28 \\
Hong Kong & NA & NA & NA & NA \\
Netherlands & 2 & 4 & 4 & 9 \\
UK & 19 & 48 & 11 & 6 \\
Sweden & 6 & 15 & 13 & 7 \\
\hline
\end{tabular}

Source: Axel, D. (2006), Updated in: Axel, D., Gaston, N., \& Martens, P. (2008).

Global trade comprises of trade in merchandise and commercial services. Merchandise trade includes exports and imports of goods (Pathak, Bhagat, \& Kashlak, 2006). Though all the world countries participate in merchandise trade, some countries lead merchandise exports and imports. In terms of global merchandise exports, out of the top-10 globally competitive countries USA occupied the second position, Germany occupied the third position, Japan and Netherlands occupied the fourth, and the fifth positions respectively among the top-10 leading exporters of world merchandise in 2012. Other top-10 globally competitive countries like UK (the 11th position), Singapore (the 14th position), Switzerland (the 25th position), and Sweden (the 28th position) were out of the top-10 leading exporters of global merchandise in 2012. However, Finland though it was in the fourth position of top-10 globally competitive countries, it failed to be in the top-40 leading exporters of merchandise in 2012. USA was the largest global importer of merchandise with a share of $12.6 \%$ of global imports. Top-10 globally competitive countries like USA, Germany, Japan, Netherlands, UK, and Hong Kong were also among the top-10 leading merchandise importing countries in 2012. Other top-10 globally competitive countries like Singapore (the 14th position), Switzerland (the 24th position), and Finland (the 40th position) were out of the top-10 leading merchandise importing countries in 2012.

The USA was the largest exporter of commercial services followed by United Kingdom and Germany respectively in 2012. Other top-10 globally competitive countries that were among the top-10 leading countries of commercial services in 2012 include Japan (the 6th position), Netherlands (the 9th position), and Hong Kong (the 10th position). Other top-10 globally competitive countries like Singapore (the 12th position), Switzerland (the 16th position), and Sweden (the 18th position) were out of top-10 leading exporters of commercial services. However, Finland though it was in the fourth position of top-10 globally competitive countries, it failed to be in the top-40 leading exporters of commercial services in 2012. The USA was also the largest importer of 
commercial services followed by Germany, Japan, UK, Netherlands, and Singapore in the order of their shares in global commercial services imports in 2012. Other top-10 globally competitive countries that were placed out of top-10 leading importers of commercial services in 2012 were Hong Kong (the 21st position), Switzerland (the 26th position), and Finland (the 33rd position).

Globally competitive economies are also expected to spend significant amount on research and development for further advancement of technology as well as for innovation. Table 3 presents top 10 countries in 2011 in terms of amount of expenditure on research and development. USA bagged the top rank with an expenditure of $\$ 405.3$ billion (PPP) followed by China and Japan. India occupied the eighth rank. However, Israel occupied the first position in terms of percentage of expenditure on research and development to GDP (4.39\%) in 2011 followed by Finland (3.78\%) and South Korea (3.74\%). However, among the top-10 globally competitive economies, only USA, Japan, and Germany could find a place in top-10 countries in terms of spending on research and development in 2011.

Table 3

Top 10 Countries in Terms of Spending on Research \& Development in 2011

\begin{tabular}{llll}
\hline Rank & Country & $\begin{array}{l}\text { Expenditure on R\&D } \\
\text { ( in billions of \$) (PPP) }\end{array}$ & $\begin{array}{l}\text { Percentage of expenditure on } \\
\text { R\&D to GDP (PPP) }\end{array}$ \\
\hline 1 & USA & 405.3 & 2.7 \\
2 & China & 296.8 & 1.97 \\
3 & Japan & 160.3 & 3.67 \\
4 & Germany & 69.5 & 2.3 \\
5 & South Korea & 55.8 & 3.74 \\
6 & France & 42.2 & 1.9 \\
7 & UK & 38.4 & 1.7 \\
8 & India & 36.1 & 0.9 \\
9 & Canada & 24.3 & 1.8 \\
10 & Russia & 23.8 & 1.0 \\
\hline
\end{tabular}

Source: www.enwikpedia.org.

Top globally competitive countries are also expected to impose lower tariff rates compared to less competitive countries as they are strong in macro-economics. Table 4 presents the average tariff rates of selected countries in 2012. It is observed from Table 4 that the rate of tariff was just $0.00 \%$ in Hong Kong, where as it was $6.5 \%$ among the top- 10 globally competitive countries. The tariff rate in non-top 10 globally competitive countries like Australia and Canada was less than that of top-10 globally competitive countries in 2012. It is, thus, clear that some of the top-10 globally competitive countries performed less than that of non-top 10 globally competitive countries in fixing tariff rates.

Globally competitive countries attract foreign direct investment and also provide foreign direct investment (FDI) to various other less competitive countries. Table 5 provides the largest recipients and providers of FDI in 2012. It is observed from this table that among the top-10 globally competitive counties, the USA was the largest recipient of FDI followed by Hong Kong (3rd position), UK (6th position), and Singapore (8th position) among the largest recipient countries of FDI in 2012. Other top-10 globally competitive countries like Switzerland, Finland, Germany, and Netherlands could not find a place among the largest recipient countries of FDI in 2012. China was the second largest recipient of FDI, even though it was not one among the top-10 globally competitive countries. 
Table 4

Average Tariff Rates in Selected Countries on All Products in 2012

\begin{tabular}{llll}
\hline Top 10 globally & Competitive countries & Globally less & Competitive countries \\
\hline Country & Simple average tariff rate & & Simple average tariff rate \\
Hong Kong & $0.00 \%$ & Australia & $2.7 \%$ \\
Japan & $4.6 \%$ & Canada & $4.3 \%$ \\
Singapore & $0.2 \%$ & China & $9.6 \%$ \\
Switzerland & $6.5 \%$ & India & $13.7 \%$ \\
USA & $3.4 \%$ & Malaysia & $6.5 \%$ \\
& & Russian Federation & $7.6 \%$ \\
\hline
\end{tabular}

Source: World Trade Organization-World Tariff Profile 2013.

It is further observed from Table 5 that among the top- 10 globally competitive countries the USA was the largest provider of FDI followed by Japan (2nd position), Hong Kong (4th position), UK (5th position), Germany (6th position), Switzerland (9th position), Sweden (12th position), and Singapore (16th position) among the largest providers of FDI. Thus, Sweden and Singapore which were among the top-10 globally competitive countries could not have a position among the top-10 providers of FDI in 2012. Similarly Finland and Netherlands which were among the top-10 globally competitive countries could not find a position among the top-16 providers of FDI in 2012. In addition, the top-10 globally competitive countries could not retain their ranks in the providers of FDI.

However, China occupied the 3rd position among the top-16 providers of FDI in 2012 even though it was not one among the top-10 globally competitive countries.

Table 5

Largest Recipients and Providers of FDI in 2012 (in Billions of US \$)

\begin{tabular}{llll}
\hline & Largest recipients of FDI & & Largest providers of FDI \\
\hline Country & Amount & Country & Amount \\
\hline USA & 168 & USA & 329 \\
China & 121 & Japan & 123 \\
Hong Kong & 75 & China & 84 \\
Brazil & 65 & Hong Kong & 84 \\
British Virgin Islands & 65 & UK & 71 \\
UK & 62 & Germany & 67 \\
Australia & 57 & Canada & 54 \\
Singapore & 57 & Russia & 51 \\
Russia & 51 & Switzerland & 44 \\
Canada & 45 & British Virgin Islands & 42 \\
Chile & 30 & France & 37 \\
Ireland & 29 & Sweden & 33 \\
Luxemburg & 28 & South Korea & 33 \\
Spain & 28 & Italy & 30 \\
India & 26 & Mexico & 26 \\
& & Singapore & 23 \\
\hline
\end{tabular}

Source: UNCTAD World Investment Report, 2013. 
Top-10 globally competitive countries are further expected to carry business ethically, though ethical issues vary from country to country. There are certain common issues of unethical practices of international business like corruption, money laundering, and software piracy.

Corruption is a major unethical practice and obstacle of not only domestic business but also international business. Transparency International constructed the corruption perception index for various years. Table 6 presents the corruption perceptions index for the year 2014, 2013, and 2012 for selected countries. The Corruption Perceptions Index ranks countries and territories based on how corrupt their public sector is perceived to be. A country or territory's score indicates the perceived level of public sector corruption on a scale of $0-100$, where 0 means that a country is perceived as highly corrupt and 100 means it is perceived as very clean. A country's rank indicates its position relative to the other countries and territories included in the index.

Table 6

Corruption Index for the Year 2014, 2013, and 2012 for Selected Countries

\begin{tabular}{|c|c|c|c|c|}
\hline Rank & Country & 2014 score & 2013 score & 2012 score \\
\hline 1 & Denmark & 92 & 91 & 90 \\
\hline 2 & New Zealand & 91 & 91 & 90 \\
\hline 3 & Finland & 89 & 89 & 90 \\
\hline 4 & Sweden & 87 & 89 & 88 \\
\hline 5 & Norway & 86 & 86 & 85 \\
\hline 5 & Switzerland & 86 & 85 & 86 \\
\hline 7 & Singapore & 84 & 86 & 87 \\
\hline 8 & Netherlands & 83 & 83 & 84 \\
\hline 9 & Luxembourg & 82 & 80 & 80 \\
\hline 10 & Canada & 81 & 81 & 84 \\
\hline 11 & Australia & 80 & 81 & 85 \\
\hline 12 & Germany & 79 & 78 & 79 \\
\hline 12 & Iceland & 79 & 78 & 82 \\
\hline 14 & United Kingdom & 78 & 76 & 74 \\
\hline 15 & Belgium & 76 & 75 & 75 \\
\hline 15 & Japan & 76 & 74 & 74 \\
\hline 17 & Barbados & 74 & 75 & 76 \\
\hline 17 & Hong Kong & 74 & 75 & 77 \\
\hline 17 & Ireland & 74 & 72 & 69 \\
\hline 17 & United States & 74 & 73 & 73 \\
\hline 21 & Chile & 73 & 71 & 72 \\
\hline
\end{tabular}

Source: http://www.transparency.org/cpi2014/results.

It is observed from Table 6 that among the top-10 globally competitive countries, Finland (3rd rank), Sweden (4th Rank), Switzerland (5th rank), Singapore ( 7th rank), and Netherlands (8th rank) could find a place among the top-10 globally corruption clean countries. Other top-10 globally competitive countries like Germany, UK, Japan, Hong Kong, and USA could find a place among the top-11 to 20 globally corruption clean countries in 2012, 2013, and 2014.

It is further observed that though Switzerland occupied the first position among the top- 10 globally competitive countries, it was placed in the 5th position in corruption-free countries in 2012, 2013, and 2014 
contrary to Sweden that occupied the 10th position among top-10 globally competitive countries occupied the 4th position among the corruption free countries. The USA which occupied the third position among top-10 globally competitive countries occupied the 17th positon among the corruption free countries.

The Basel AML Index is an annual ranking assessing country risk regarding money laundering/terrorism financing. It focuses on anti-money laundering and counter terrorist financing (AML/CTF) frameworks and other related factors such as financial/public transparency and judicial strength. The scale ranges from 0 (low risk) to 10 (high risk). Table 7 provides Basel AML Index for the year of 2015 for the top-10 globally competitive countries and selected non-top-10 globally competitive countries. It is observed from this table that the risk level of money laundering and terrorist financing is above moderate level (moderate level is 5.00) for Japan (5.80), Hong Kong (5.52), Switzerland (5.51), Germany (5.48), and the USA (5.18). Thus, it is clear that money laundering and terrorist financing risk is high in Hong Kong, Switzerland, Germany, and the USA. Risk level of money laundering and terrorist financing is less than moderate for Singapore (4.91), UK (4.68), Sweden (3.99), and Finland (2.53). Risk level of money laundering and terrorist financing was the lowest in Finland. It was further observed from this table that the risk level of money laundering and terrorist financing is relatively less in non-top-10 globally competitive countries than that of top-10 globally competitive countries. These countries include India (5.77), South Korea (5.20), Australia (4.94), Norway (4.60), New Zealand (3.78), Lithuania (3.67), and Estonia (3.19). Thus, performance of some of the top-10 globally competitive countries in maintaining low risk level of money laundering and terrorist financing was not satisfactory as it was above moderate level.

Table 7

Base AML Index for 2015

\begin{tabular}{llll}
\hline $\begin{array}{l}\text { Top-10 Globally competitive } \\
\text { countries }\end{array}$ & AML Index & $\begin{array}{l}\text { Non top-10 globally } \\
\text { competitive countries } \\
\text { (Selected only) }\end{array}$ & AML Index \\
\hline Switzerland & 5.51 & Iran & 8.59 \\
Singapore & 4.91 & Thailand & 6.52 \\
USA & 5.18 & Papua New Guinea & 6.11 \\
Finland & 2.53 & India & 5.77 \\
Germany & 5.48 & South Korea & 5.20 \\
Japan & 5.80 & Norway & 4.60 \\
Hong Kong & 5.52 & Australia & 4.94 \\
Netherlands & 5.02 & New Zealand & 3.78 \\
UK & 4.68 & Lithuania & 3.67 \\
Sweden & 3.99 & Estonia & 3.19 \\
\hline
\end{tabular}

Source: https://index2015.baselgovernance.org/ranking.

Business Software Alliance (BSA) has been studying global trends in personal computer software piracy for more than a decade. Table 8 depicts the rate of software piracy in top-10 globally competitive and non-top-10 globally competitive countries. It is observed from Table 8 that the USA (software piracy rate of 20\%) ranked first among the countries with the lowest rate of software piracy followed by Japan (software piracy rate of 21\%) in 2009. Luxembourg (software piracy rate of 21\%) ranked first with the lowest rate of software piracy followed by Belgium (software piracy rate of 25\%), Australia (software piracy rate of 25\%), and Austria (25\%) among the non-top-10 globally competitive countries in 2009. All other (other than the USA 
and Japan) top-10 globally competitive countries had the rate of software piracy either equal to or higher than $25 \%$. It is heartening to note that even though Hong Kong was the 7th globally completive country in the world, it experienced software piracy as high as $47 \%$ in 2009. Rate of software piracy in Hong Kong was even higher than all other countries in 2009.

Table 8

Software Piracy Rates in 2009

\begin{tabular}{|c|c|c|c|}
\hline $\begin{array}{l}\text { Top-10 globally competitive } \\
\text { countries }\end{array}$ & Software piracy rate (\%) & $\begin{array}{l}\text { Non top-10 globally } \\
\text { competitive countries } \\
\text { (selected only) }\end{array}$ & Software piracy rate (\%) \\
\hline Switzerland & 25 & Luxembourg & 21 \\
\hline Singapore & 35 & Belgium & 25 \\
\hline USA & 20 & Australia & 25 \\
\hline Finland & 25 & Austria & 25 \\
\hline Germany & 28 & Canada & 29 \\
\hline Japan & 21 & Norway & 29 \\
\hline Hong Kong & 47 & Denmark & 26 \\
\hline Netherlands & 28 & New Zealand & 22 \\
\hline UK & 27 & France & 40 \\
\hline Sweden & 25 & Ireland & 35 \\
\hline
\end{tabular}

Source: http://chartsbin.com/view/1186.

\section{Conclusion}

Analysis of these factors indicates that the top globally competitive countries could not exhibit corresponding performance in the globalization levels, global trade, investment in research and development, corruption levels, money laundering and terrorist financing, and software piracy. Therefore, it is suggested that these countries should implement the practices that would reflect their position as one of the top globally competitive countries.

\section{References}

Pathak, A. V., Bhagat, R. S., \& Kashlak, R. J. (2006). International management. New Delhi: Tata Mc Graw Hill Publishing Company Limited.

Axel, D. (2006). Does globalization affect growth? Empirical evidence from a new index. Applied Economics, 38(10), $1091-1110$. Axel, D., Gaston, N., \& Martens, P. (2008). Measuring globalization-Gauging its consequence. New York, NY: Springer.

Deresky, H. (2004). International management, New Delhi: Prentice Hall of India Private Limited.

http://globaledge.msu.edu/global-resources/433

http://www.ed.ac.uk/information-services/research-support/data-library/finding-data/kof (Accessed on 12th September2015)

http://globalization.kof.ethz.ch/static/pdf/rankings_2013.pdf (Accessed18/12/2015)

http://globalization.kof.ethz.ch/media/filer_public/2015/.../rankings_2015.pdf (Accessed on 18th December 2015)

http://www.weforum.org/reports/global-competitiveness-report-2014-15 (Accessed on 14th December 2015)

http://chartsbin.com/view/1186 (Accessed on 14th December 2015)

http://www.transparency.org/cpi2014/results (Accessed on 11th November 2015)

https://index2015.baselgovernance.org/ranking (Accessed on 11th November 2015)

Mead, R. (2005). International management. Malden: Blackwell Publishing.

Hodgetts, R. M., Luthans, F., \& Doh, J. P. (2008). International management. New Delhi: Tata Mc Graw Hill Publishing Company Limited.

Subba, R. P. (2014). International business. Mumbai: Himalaya Publishing House (P) Limited. 
The Global Competitiveness Report 2014-15. World economic forum, 2014-15 (p. 4). Retrieved from http://www.enwikpedia.org (Accessed on 15th January 2016)

UNCTAD, World Development Report, 2013.

World Economic Forum, 2014-15. Retrived from http://www.weforum.org/reports/global-competitiveness-report-2014-15

Trade

Organization-World

Tariff

Profile

2013.

Retrived

from 